\title{
CRM System: the Role of Dynamic Capabilities in creating Innovation Capability
}

\author{
Cristiane Drebes Pedron ${ }^{1, \dagger}$ \\ ${ }^{1}$ Universidade Nove de Julho, Porto Alegre, Rio Grande do Sul, Brazil \\ Winnie $\mathrm{Ng}$ Picoto ${ }^{2, \Omega}$ \\ ${ }^{2}$ Universidade de Lisboa Instituto Superior de Economia e Gestão, Lisboa, Portugal \\ Miguel Colaco $3, ¥$ \\ ${ }^{3}$ Universidade de Lisboa Instituto Superior de Economia e Gestão, Lisboa, Portugal \\ Cintia Cristina Araújo 4,* \\ ${ }^{4}$ Universidade Nove de Julho, São Paulo, São Paulo, Brazil
}

\section{ABSTRACT}

Customer relationship management (CRM) is a topic discussed, mainly, by information systems and marketing management areas. Many organizations are already using CRM systems. When a company uses CRM, it develops different organizational capabilities some of which lead to innovation. Whilst there are some studies that already analyze the creation of innovation capabilities resulting from the usage of a CRM system, how this is achieved has not been understood. The present study aims to contribute to this debate by building on the dynamic capabilities theory to develop a conceptual model for understanding the innovation capabilities development through CRM usage. The research question that guides this paper is: "What is the role of Dynamic Capabilities in the creation of innovation capabilities through CRM usage?" We conduct an exploratory study based on qualitative experts' interviews. Our findings support the argument that CRM drives innovation through dynamic capabilities. In fact, by sensing, seizing and reconfiguring market opportunities and threats, CRM allows organizations to generate innovation.

Keywords: CRM, Innovation Capability, Dynamic Capabilities.

\section{INTRODUCTION}

Competitiveness and superior performance are among the top priority issues for many organizations. The building of innovation capabilities can help organizations to achieve competitive advantages (SMITH, 2017; SAUNILA, 2016; JENG; PAK, 2014). The usage of Information Technologies can be a way to improve and enhance innovation capability in an organization. The concept of customer relationship management (CRM) is often discussed in the academic milieu; however, there are several possible definitions and a consensus we have not reached yet (NGAI et al., 2009). CRM might be seen as a company's overall strategy designed to optimize profitability and customer satisfaction through the internal organization of the company, based on customer segments. CRM aims to ensure value creation, both for the company, and its customers (NGAI et al., 2009). Over the last years, organizations have adopted CRM systems with the objective of improving
Corresponding author:

† Universidade Nove de Julho, Porto Alegre, Rio Grande do Sul, Brazil

E-mail: cdpedron@gmail.com

$\Omega$ Universidade de Lisboa Instituto Superior de Economia e Gestão, Lisboa, Portugal

E-mail: w.picoto@iseg.ulisboa.pt

${ }^{¥}$ Universidade de Lisboa Instituto Superior de

Economia e Gestão, Lisboa, Portugal

E-mail: miguel.sa.nogueira@gmail.com

* Universidade Nove de Julho, São Paulo, São

Paulo, Brazil

E-mail: cintyaraujo@gmail.com

Received: 09/04/2017.

Revised: 10/11/2017.

Accepted: 01/26/2018

Published Online: 06/28/2018.

DOI: http://dx.doi.org/10.15728/bbr.2018.15.5.6 
operational performance, profits and market share (REINARTZ et al., 2004; PEDRON et al., 2016). However, even though organizations invest on costly CRM systems, they have not always been able to achieve the full potential of CRM (KHODAKARAMI; CHAN, 2014). One possible explanation for that is the fact that organizations lack on understanding the changes in strategy and business processes that they should carry out in order to leverage the adoption of a CRM system (CHEN; POPOVICH, 2003). Throughout this learning and changing process, organizations are able to achieve one of the most important benefits of CRM adoption - the development of innovation capability (TEECE, 2007).

Desai et al. (2007) conducted a study about the importance to continuously improve, innovate and reconfigure the organizational resources in order to achieve competitive advantage through CRM usage. According to them, there is a set of CRM dynamic capabilities (resource re-configurability, social network capability and market orientation) that enhance the CRM initiative. In this same vein of research, Lin et al. (2010) propose a framework linking CRM practices and innovation capabilities. Considering these arguments, the present paper proposes to further analyze the link between CRM usage and innovation capability, through the theoretical lens of dynamic capability (TEECE, 2007). To accomplish that, the following research question guides the development of this paper: "What is the role of Dynamic Capabilities in the creation of innovation capabilities through CRM usage?" To answer this research question, we performed a comprehensive literature review regarding CRM and innovation capability. An exploratory study applying content analysis to qualitative experts' interviews investigates the possible link between CRM system adoption and innovation capability, resulting on a research model.

The next section presents the literature review, followed by the research methods, discussion of results, the research model presentation and the final remarks.

\section{THEORETICAL BACKGROUND}

This section presents the main concepts of the three constructs of this study: CRM, innovation capability and dynamic capabilities.

\subsection{Customer Relationship Management}

In this paper, we define CRM as an "enterprise approach to understanding and influencing customer behavior through meaningful communications, in order to improve customer acquisition, customer retention, customer loyalty, and customer profitability" (SWIFT, 2001, p. 21). CRM can be seen as a company's overall strategy, designed to optimize profit and customer satisfaction through the internal organization of the company, based on customer segments, in order to ensure value creation for both the company and customers (NGAI et al., 2009). Indeed, companies are facing high levels of competition, constant changes in customer needs and ever growing market demands (WEI-WEI; DONG-SHENG, 2010). The knowledge that companies have about their customers is a very important resource (KHODAKARAMI; CHAN, 2014). By combining good organizational structure, processes and personal skills, companies may successfully create customer knowledge (KHODAKARAMI; CHAN, 2014). Therefore, CRM can be seen as the combination of processes, human resources and technology (MENDONZA et al., 2007).

In order to create, maintain, and re-establish a long-term relationship with customers, companies implement relationship-marketing principles, by implementing organizational changes. The implementation of relationship marketing principles, combined with CRM systems usage, can also be a way to successfully achieve customer loyalty (CHEN; POPOVICH, 2003). CRM systems are not just technological applications that support operations, but rather a "cross functional, customer-driven, technology-integrated business process management that maximizes relationships 
BBR

and encompasses the entire company" (CHEN; POPOVICH, 2003, p. 673). CRM systems enable the collection, storage and analysis of customer data in order to provide a comprehensive view of an organization's customers and all the activities related to them (KHORADAKARAMI; CHAN, 2014).

\subsection{Innovation Capability}

Innovation can be defined as the process of using a new idea or concept for a product, service, business model or process that will create or add value, and which will make the customer pay for it (TEECE, 2010; FOROUDI, 2016). In order to achieve innovation and consequently competitive advantage, the organization needs to obtain information about the market and its customers (BRYSON, 2011). The sources of information can be either internal or external (BRYSON, 2011). Regarding internal sources, employees are a very important asset, given their contribution to new product development and to other innovation activities, which may not be on their assigned job functions (SMITH et al., 2017). Employees have inside information about the business namely about products, resources and processes that can be converted into new ideas, new products and new business processes if they are involved in innovation activities (SMITH et al., 2017). The other source of information is external, in which knowledge regarding competitors, customers and market trends are good indicators about the new business opportunities (BRYSON, 2011).

In order to be innovative and achieve superior competitive advantages, organizations must develop innovation capabilities (SMITH, 2017; JENG; PAK, 2016). Innovation capability is the ability of an organization to present and develop new ideas to the market leading to competitive advantages and enhancements of profit in either a short or a long term (NISULA; KIANTO, 2013). Additionally, innovation capability may be defined as the ability to develop products that meet market needs through technology (ADLER; SHENBAR, 1990), creating new resources and producing products and services more efficiently and better than competitors (JENG, 2014). Saunila (2016, p.164) presents a review of several definitions of innovation capabilities that exist in the literature and proposes that innovation capability means a "potential or ability to produce innovations", it is an "internal capability", it "requires continuous improvement" and it "aims to add value".

The Ernst \& Young Corporation (2011) suggests that organizations may achieve innovation capability at a perfect level through customer insight, people and culture, research and development and operations and business models. The use of innovation capability as a managerial tool is explored by Foroudi et al. (2016) linking this capability to the capacity of building a customers' loyalty and brand recognition. Interestingly, Jeng and Pak (2014, p. 126)'s research results show that "complementarity of innovation and marketing capabilities is the best determinant of firms performance". In fact, the operations and business model should be changed in order to achieve innovation capability, as it should include products or services that better suit their clients' needs (ERNST \& YOUNG, 2011).

Lin et al.'s (2010) framework proposes a link between Customer Relationship Management and innovation capability. The implementation of CRM systems enables organizations to develop stronger and long-term customer relationships, which may directly impact the organization's innovation capability. Additionally, there are four dimensions of CRM activities that are based on the interactions between the organization and its customers: (1) Information sharing; (2) Customer involvement; (3) Long-term Relationship, and; (4) Technology-based CRM (LIN et al., 2010). Figure 1 illustrates the CRM practices and innovation capabilities proposed by Lin et al. (2010). 
- Information sharing

- Customer involvement

- Long-term partnership

- Joint problem-solving

-Technology-based CRM
- Product Innovation

- Process Innovation

- Administrative Innovation

- Marketing Innovation

- Service Innovation

Figure 1. Lin's framework - relationship between CRM practices and Innovation Capabilities Source: Lin et al. (2010, p. 119)

The literature review on the relationship between CRM and innovation capabilities is very restricted and recent, and, although it is not yet fully understood, CRM is expected to have a positive effect on the innovation capabilities of an organization (LIN et al., 2010; ZABLAH et al., 2004). Tables A1 and A2 in the Appendix present a summary of the existing research on CRM and innovation capability, as well as on CRM and dynamic capabilities, respectively.

\subsection{Dynamic Capabilities}

Teece et al. (1997, p. 516) define dynamic capabilities as "the company's ability to integrate, build and reconfigure internal and external competence to address rapidly changing environments". The concept of dynamic capabilities was introduced in order to explain how a company can create and maintain competitive advantage for a long period of time and in a dynamic environment (TEECE et al., 1997). The Foundations of Dynamic Capabilities Framework (TEECE, 2007) points out three components of dynamic capabilities: (1) the capacity to sense and shape opportunities and threats; (2) the capacity to seize opportunities, and; (3) the capacity to maintain competitiveness. According to Teece et al. (1997, p. 1319), organizations can develop dynamic capabilities by "enhancing, combining, protecting and, if necessary, reconfiguring the business assets". The three main components of the framework also comprise a micro foundation (TEECE, 2007). A micro foundation is a set of "capabilities necessary for sustaining the superior performance of an enterprise in an open economy with rapid innovation and globally-dispersed sources of invention, innovation and manufacturing capability" (TEECE, 2007, p. 1320).

Sensing opportunities and threats component of dynamic capabilities refers to the processes of identifying threats in the market in order for an organization to have a quick response to situations that affect the market and its customers. In terms of sensing opportunities and threats in the market, information systems help identifying knowledge, particularly analytical systems concerning customers (TEECE, 2007). Seizing opportunities component can lead the organization to succeed or to fail. The micro foundation suggests the optimal achievement of opportunities by: (i) delineating customer solution and business model; (ii) selecting decision-making protocols; (iii) selecting enterprise boundaries to manage complements and control platforms, and; (iv) building loyalty and commitment (TEECE, 
BBR

2007). Finally, 'managing threats and reconfiguration' is an important strategic component translating the ability to reconcile an organizational structure and resources along with the evolution of the market. In order to manage threats and reconfiguration correctly, it is necessary to align the micro foundation by: (1) decentralization and near decomposability; (2) governance; (3) co-specialization, and; (4) knowledge management reconfiguration.

Desai et al. (2007) investigate the main effects of IT and dynamic capability on competitive performance of a CRM process. They consider three main CRM dynamic capabilities. The first one is resource re-configurability, meaning the re-configuration and integration of existing resources (people, process and technology) in new ways. Second, social network capability as in order to renew resources for CRM, organization must manage relationships with the key suppliers, customers and other stakeholders. Third, market orientation to sense and adapt company's resources rapidly according to competitive dynamic and customer needs. The authors argue that there is significant importance of external relationship and social networking capability in driving dynamic capability for CRM. Their findings also showed that CRM technology could lead to competitive performance if there is the right set of dynamic capability.

\section{RESEARCH METHODS}

In order to answer the research question this study conducts a comprehensive literature review about CRM and Innovation Capabilities, following the approach proposed by Khodakarami and Chan (2014). The following list has some of the top journals in the field of management information systems, marketing and innovation and are considered in this study: Management Information Systems Quarterly, Information System Research, Journal of Management Information Systems, Communications of the Association for Computing Machinery, European Journal of Information System, Decision Support System and Information \& Management, Academy of Management Journal, Academy of Management Review, Strategic Management Journal, Journal of Management Studies and Technovation.

The search was conducted in the three main digital libraries (B-On, Science Direct and Google Scholar), to ensure that we had sufficient relevant papers about the subject in question between 2000-2014 and with keywords Customer Relationship Management, Innovation Capability and Dynamic Capability. The first search by not relating those keywords resulted in an extraction of 825 papers. It enabled us to have an initial recognition of the theory behind each construct: Dynamic Capability (190 papers), the ResourceBased View (332 papers), Innovation Capability (226 papers), and Customer Relationship Management (303 papers). In view of exploring the concepts mentioned above, we crossed the data resulted from the extraction of each key construct: "Customer Relationship Management and Innovation Capability" and "Customer Relationship Management and Dynamic Capabilities" (Appendix).

The results from the systematic literature review allow us developing the interview guide. Although all relevant papers found in the literature review were important to better understand and theoretically conceptualize the research topic, the questions are mainly from the studies by Khodakarami and Chan (2014), Beldi et al. (2010) and Raman et al. (2006). The interview guide has four main categories as shown in Appendix 1: (1) introduction; (2) CRM in the organization; (3) the evaluation of the CRM system, and; (4) CRM and innovation capability. However, in order to have a deeper insight of the role of CRM systems in organizational innovation capability we can add other questions. Given the exploratory nature of this research, the interviews are non-standardized and semi-structured.

As we intended to conduct interviews with experts, the interviewees were selected based on their knowledge and professional experience on CRM, including CRM consultants, academics, clients and vendors. Table 1 presents the profile of each interviewee. We performed a total of 8 interviews during the period of August 13th and September 10th of 2015. The 
interviewees were carefully selected considering the complexity of the topic under study and the interviewees' diversity in terms of background, so we could cover different and complementary perspectives of the topic (YIN, 2011). On the eighth interview we found no additional insights and did not identify any new codes (GUEST et al., 2006), indicating that we had reached theoretical saturation (GLASER, STRAUSS, 1967) and no more interviews were considered necessary. The interviews were audio-recorded (under interviewee's permission) and transcribed (SAUNDERS et al., 2009).

Table 1: Interviewees' profile

\begin{tabular}{lccc}
\hline Interview ID & Interviewees' Profile & Date of Interview & Duration \\
\hline E1 - PGA & CRM academic & $08 / 13 / 2015$ & 1 hour \\
E2 - AM & CRM specialist & $08 / 18 / 2015$ & 1 hour \\
E3 - JF & Information system academic & $08 / 26 / 2015$ & 45 minutes \\
E4 - MR & CRM academic & $08 / 28 / 2015$ & 1 hour \\
E5 - RL & CRM consultant & $09 / 01 / 2015$ & 1 hour \\
E6 - LG & CRM consultant & $09 / 02 / 2015$ & 1 hour \\
E7 - LM & Salesforce director & $09 / 03 / 2015$ & 30 minutes \\
E8 - PE & CRM consultant & $09 / 09 / 2015$ & 1 hour \\
\hline
\end{tabular}

NVIVO 10 software supports the analysis of the interview data. This software was selected because it supports the analysis of non-numerical and unstructured data (GIBBS, 2002). Besides that, NVIVO 10 is adequate to apply the technique and assumptions proposed by Bardin (1977) regarding content analysis. All the categories and sub-categories of codes derived from the systematic literature review (BARDIN, 1977). Data analysis followed a two steps approach. First, we code CRM practices (information sharing, customer involvement, long-term relationship, and technology-based CRM) and innovations (product innovation, process innovation, marketing innovation, service innovation and administrative innovation), according to Lin et al. (2010)'s categories. Then, based on those codes we search for the linkage between CRM and Innovation Capability (LIN et al., 2010) through Dynamic Capabilities (DESAI et al., 2007).

\section{DATA ANALYSIS AND RESULTS}

Content analysis with interviews data aims at uncovering the relationship between the use of CRM systems and organizational innovation capability. Using NVIVO, we perform content analysis and several queries. These queries provide some interesting evidences regarding the relationship between the statements of the interviewees. The first query performed is a word frequency query. The words with the highest frequency during the interviews are: CRM, organization, customer, system, and capabilities. This result confirms that the interview guide and the answers to the questions are aligned with the purpose of this research.

For each category and sub-category, a "node" (category) is created in the software and we classify the content of the interviews according to each of these nodes. To ensure the validity and consistency of this procedure, we reviewed the content of each interview according to the categories based on the framework by Lin et al. (2010) and the categories derived from the systematic literature review. The results of this procedure are described in Table 2.

The results show that academic or professional experience influences the focus of interviewees' knowledge. For example, an academic specialist in information systems did not mention product innovation or service innovation. The interviewee 
BBR

15,5

500

knowledge and contribution focus on CRM systems, marketing innovation and process innovation.

Table 2: Number of references in each category

\begin{tabular}{|c|c|c|c|c|c|}
\hline \multirow[t]{2}{*}{ Node name } & \multicolumn{5}{|c|}{ Interviewees' profile } \\
\hline & CRM consultants & CRM academicians & CRM specialists & Salesforce director & IT/IS academic \\
\hline CRM & 60 & 51 & 21 & 19 & 8 \\
\hline Long-term partnership & 12 & 8 & 4 & 3 & 1 \\
\hline Information sharing & 17 & 12 & 4 & 8 & 2 \\
\hline Customer involvement & 19 & 16 & 4 & 6 & 2 \\
\hline Technology-based CRM & 12 & 15 & 9 & 2 & 3 \\
\hline Innovation Capabilities & 70 & 48 & 27 & 20 & 13 \\
\hline Product innovation & 11 & 7 & 6 & 3 & 0 \\
\hline Process innovation & 30 & 16 & 11 & 11 & 7 \\
\hline Administration innovation & 14 & 15 & 3 & 3 & 3 \\
\hline Marketing innovation & 2 & 4 & 3 & 1 & 3 \\
\hline Service innovation & 13 & 6 & 4 & 2 & 0 \\
\hline
\end{tabular}

\subsection{CRM Dimensions AND ACTivities}

The interviews analysis focuses on the four dimensions of CRM activities or practices: long-term partnership, information sharing, customer involvement, and technology-based CRM. Interviewees' statements refer directly or indirectly to all those four dimensions. All interviewees agree that CRM systems can provide several benefits to the organization, but in order to achieve those benefits, the organization must change internal and external processes that deal with main stakeholders, especially customers. The long-term partnership dimension belongs to the CRM strategy for achieving innovation capability (LIN et al., 2010). The partnership between organization and its customers can be improved with the implementation of CRM systems. It is mutual partnership that brings advantages to both parties (DAY, 1994) - see Table 3. In the perspective of all interviewees, CRM systems have the capability of gathering and organizing information that can be used to create a true picture of the customer. CRM systems also have the capability to improve the relationship between the customer and the organization. Customer feedback about products and services becomes an important factor when organizations create and introduce new solutions into the market. CRM systems enable the proper treatment of this feedback, whilst enhancing the success of new products or services.

Information sharing may lead to the development of new organizational capabilities (LIN et al., 2010). CRM systems create customer databases, and provide a set of tools for managing information. Having information about the market and customers is important, and the implementation of a CRM system can be a turning point in an organization's capability to manage information (PLAKOYIANNAKI; TZOKAS, 2002). According to some of the interviewees (E1, E2, E4 and E5), information management is crucial for an organization, not only on account of information regarding customers, but also for the current necessity of having a single application to manage customer information across the entire organization. All the interviewees referred to the relevance of having a CRM application for centralizing information about customers, products, services and processes. For some interviewees, the capability of information management is one of the main attributes that organizations look for when developing and implementing a CRM system (Table 3 ). The process of transforming information into business knowledge is complex (E2 and E4). 
Table 3: Interviewees' references made by CRM dimension and activity

\begin{tabular}{|c|c|c|}
\hline Dimensions and activities & Sources & References \\
\hline CRM & 8 & 159 \\
\hline Long-term partnership & 8 & 28 \\
\hline Improving management of whatever customers suggest & 5 & 6 \\
\hline Customers provide suggestions for new products and services & 5 & 5 \\
\hline Providing customized products and services to key customers & 1 & 1 \\
\hline Actively stresses customer loyalty or retention programs & 2 & 2 \\
\hline Interactive, two way communications with customers & 5 & 6 \\
\hline Long term development and successes with customers & 4 & 8 \\
\hline Information sharing & 8 & 43 \\
\hline Sharing information with customers & 7 & 20 \\
\hline Sharing product demand with customers & 7 & 18 \\
\hline Sharing inventory information with customers & 0 & 0 \\
\hline Jointly makes production plans with customers & 3 & 3 \\
\hline Customers warns about events that affect supplying & 1 & 2 \\
\hline Customer involvement & 8 & 47 \\
\hline Customers involved in NPD activities & 1 & 1 \\
\hline Customers involved periodically reviewing operations & 8 & 20 \\
\hline Customers involved in the modification of products & 3 & 5 \\
\hline Customers involved regarding market evaluations & 5 & 12 \\
\hline Customers involved regarding processing technology & 6 & 9 \\
\hline Technology-based CRM & 8 & 41 \\
\hline Call center and contact centers used to deal with interactions with customers & 2 & 2 \\
\hline Sales force automation analyzes customer trade-off and all interactions & 7 & 10 \\
\hline MIS to collect customer trade-off information and to integrate databases & 6 & 15 \\
\hline Integrated CRM evaluation system & 5 & 6 \\
\hline Perfect web-based customer interaction & 2 & 3 \\
\hline Data warehousing and Data mining to identify potential customers & 5 & 5 \\
\hline
\end{tabular}

The Customer Involvement dimension is related with long-term partnership, as it refers to how customers are engaged in the development of new products or services, and this only happens if there is a strong partnership between organizations and their customers (LIN et al., 2010). Several interviewees (E1, E2 and E4) gave the example of the Telecom sector, which is a sector with a high level of competition between the main players, and where customer involvement in the development of new solutions has become critical, in order to maintain market share and competitive advantage. Through customer involvement, an organization is more ready to adapt its offers to market trends or to customize it to meet a specific customer need. According to references from the interviews, "customer involvement is a process that requires time" (E4). With the implementation of a CRM system, the process may have two kinds of outcomes: it can improve customer involvement and be a success, or, in some cases, it can be a complete failure, leading to a setback for the organization in its relationship with customers (WEERAWARDENA et al., 2006).

The technology-based CRM dimension is not directly referenced during the interviews. Technology investments are a sensible subject to discuss when associated with CRM, due to the complex process of CRM system implementation (MAKLAN 
BBR

et al., 2005). According to interviewees, CRM is an organizational strategy and a new mind-set, not just an information technology system. They also affirmed that CRM is a strategy that can take a business model into a different level, since it can lead the organization to become more client-oriented. According to the interviewees, a CRM system only supports and facilitates the implementation of this client-oriented strategy. A well succeed CRM adoption requires designing new organizational processes. They all agreed that CRM systems alone are not enough to achieve good results. CRM systems need to be aligned with the organizational marketing relationship strategy (CHEN; POPOVICH, 2003).

\subsection{InNovation CapabiLities}

Based on Lin et al. (2010)'s work, the innovative capabilities taken into account and analyzed in this research are product innovation, process innovation, marketing innovation, service innovation, and administrative innovation. The interviewees directly or indirectly cited these five capabilities. During the interview phase, all interviewees were asked the same question: "How would you describe innovation capability?" The answers to this particular question were rich in details. Innovation capability, according to the interviewees, is the ability of an organization to use processes, technology or people to operate more efficiently, in order to add more value to the company. This value can be financial, procedural, or both.

Product innovation refers to the ability of an organization to present and launch new products in the market and to expand its market (LIN et al., 2010). CRM systems can be a good source of product innovation, due to the analytical capabilities of this kind of systems and especially as CRM systems can lead to a more profitable interaction with customers (PAYNE, 2005), as can be seen in Table 4. According to some of the interviewees (E1, E2, E4 and E5), changing organizations' relationship with customers can be a source of inputs to innovation. This is due to the partnership that is established between the customer and the organization. Currently, given all the communication channels that organizations have available to interact with customers, and the amount of information shared, product innovation can be improved by the use of CRM systems. Then, as customers share their opinions about products and services they work alongside with the organization in the process of generating product value (GARRIDO-MORENO et al., 2010).

The second capability analyzed is process innovation. This capability is the most referenced during the interviews, with a total of 75 references (see Table 4). It refers to the creation of new organizational process or changes on existing processes. By analyzing the references regarding this capability, we can see how critical business processes are for an organization and furthermore the continuous adaptation of these processes to customer and market changes. According to the interviewees (E1, E2, E3, E4, E5 and E8), technology does not fix organizational problems. Therefore, it is essential that organizations solve their structural problems before investing in technology and, particularly, in CRM systems. Companies must be organizationally mature and should have business processes that are fully implemented and tested if they are to succeed technologically. CRM systems can be a trigger for many improvements in organizational processes, especially processes linked to customer information (KOZIOL et al., 2014). These improvements can be sensed in processes of information management and sales automation, which enable workers to perform less routine activities, according to some interviewees (E4, E5, E8). Another aspect is that CRM systems improve is the real-time control of customer relationships. This improvement has a direct impact on internal response time to customer requests. 
Table 4: Interviewees' references made by CRM dimension and activity

\begin{tabular}{|c|c|c|}
\hline Dimensions & Sources & References \\
\hline Innovation capability & 8 & 178 \\
\hline Production innovation & 7 & 27 \\
\hline Launch new products & 4 & 6 \\
\hline Extands number of product lines & 5 & 7 \\
\hline Engages in NPD to obtain patents & 0 & 0 \\
\hline Enlarges new markets & 4 & 4 \\
\hline Launch customized products according to market demands & 6 & 10 \\
\hline Process innovation & 8 & 75 \\
\hline New process technology & 8 & 40 \\
\hline Obtain process technology patents & 0 & 0 \\
\hline Adopt advanced CAD/CAM equipment & 0 & 0 \\
\hline Adopt advanced real-time process control technology & 7 & 21 \\
\hline Import advance programmable equipment & 6 & 14 \\
\hline Administrative innovation & 8 & 38 \\
\hline Adopt innovative reward systems & 0 & 0 \\
\hline Adopt innovative work designs & 3 & 5 \\
\hline Adopt innovative administration aiming at NPD & 0 & 0 \\
\hline Engages in organizational reconstruction for pursuing operational efficiency & 8 & 16 \\
\hline Engages in business process re-engineering & 8 & 17 \\
\hline Marketing innovation & 6 & 13 \\
\hline Leads innovative pricing methods in markets & 0 & 0 \\
\hline Leads innovative distributing methods to markets & 0 & 0 \\
\hline Leads innovative promoting methods to markets & 2 & 3 \\
\hline Continually enlarges potential demand market & 3 & 4 \\
\hline Utilizes advances CRM systems in markets & 5 & 6 \\
\hline Service innovation & 7 & 25 \\
\hline Imports innovative systems to enhancing customer satisfaction & 7 & 13 \\
\hline Imports innovative claim clearing procedures and methods & 2 & 5 \\
\hline Imports innovative sales support service methods & 5 & 7 \\
\hline Adopts innovative order management and follow-up systems & 0 & 0 \\
\hline
\end{tabular}

Administrative innovation is the ability of an organization to execute and adopt new work methodology and to achieve operational efficiency (LIN et al., 2010). This involves exploring the current business model of the organization and trying to find innovative ways of carrying out the business processes more efficiently. Interviewee E4 said that administrative innovation "can be improved with CRM systems with regards to the business processes associated with customers". CRM systems can help an organization achieving operational efficiency through operational reconstruction and business process re-engineering. The operational reconstruction and business process reengineering must be supported along the organization structure if they are to succeed, and must be aligned with the business strategy. CRM system implementation must be part of that strategy if it is to accomplish operational efficiency, otherwise CRM will fail and the business processes will be inefficient (CHEN; POPOVICH, 2003).

Marketing innovation was the less mentioned capability during the interviews. This capability concerns the ability of an organization to innovate in pricing and
BBR 15,5 
promotion methods, and the ability to enlarge potential market demand (LIN et al., 2010). According to some interviewees (E1, E4 and E5), CRM systems can create a dynamic interdepartmental interaction, in which the marketing area plays a fundamental role. CRM systems must be transversal in the organization, and marketing must improve their processes, based on customer feedback and internal experience (PAYNE, 2005).

Service innovation is the ability of an organization to enhance customer satisfaction. Improving customer satisfaction must be a continuous process (LIN et al., 2010). According to some of the interviewees (E4 and E5), a business plan only works when customers are satisfied at all levels. Service innovation can be accomplished with technological resources, such as a CRM system. Since CRM systems can potentially increase the relationship with customers, this kind of information system is suitable for enhancing customer satisfaction.

\subsection{Linking CRM AND InNOVATION CAPABILITIES THROUgh DyNAMilC CAPABILITIES}

Desai et al. (2007) unpacked the black box of dynamic capability for CRM in three different capabilities: (1) marketing orientation, (2) resource re-configuration and (3) social networking capability. Table 5 presents the codification about this data analysis category.

Table 5: Interviewees' references regarding CRM Dynamic Capabilities

\begin{tabular}{|c|c|c|c|c|c|c|c|c|c|}
\hline Node Name & Interview ID & Number of References & & & & & & & \\
\hline & E1-PGA & E2-AM & E3-JF & E4-MR & E5-RL & E6-LG & E7-LM & E8-PE & \\
\hline CRM Dynamic Capability & 23 & 23 & 5 & 10 & 11 & 8 & 5 & 7 & 94 \\
\hline Marketing Orientation & 10 & 6 & 1 & 4 & 2 & 1 & 1 & 2 & 27 \\
\hline Resource Re-configuration & 9 & 15 & 4 & 6 & 7 & 3 & 4 & 3 & 51 \\
\hline Social Networking Capability & 6 & 2 & 0 & 0 & 2 & 4 & 0 & 2 & 16 \\
\hline
\end{tabular}

Along the interviews, the most commented capability is "resource re-configuration". This capability refers to the integration of existing resources to creatively shape new competences (DESAI et al., 2007). One of the most cited organizational resource that suffers re-configuration with CRM is "processes". Companies improve processes in order to (1) serve the customer with greater agility (E1), (2) add value in a process (E6), (3) fit organizational processes with CRM software (E2), and (4) improve organizational capabilities (E7, E8). Another resource that changes with a CRM initiative are technological tools, because companies can adopt CRM technology step by step (E7) while CRM suppliers develop new software features (E5).

One interviewee (E1) argues that more important than to re-configure resources as processes or technologies is to re-configure values and the company's culture. In fact, the CRM initiative needs a philosophy based on good relationships with customers and all kind of stakeholders. The reconfiguration of resources must happen across the entire company (involving different departments), and all people should start to work together (E3). CRM adoption will add value to an organization if employees are committed with new values and a new way of work (E6). Indeed, companies should develop a learning-based culture in order to be able to understand and to create knowledge from their customers (E1) or employees (E6). With a CRM adoption, companies may automatize many organizational routines and employees could have 
more time to focus on more creative activities (E2 and E3). This will allow companies be more innovative (E2).

The second most cited capability was "market orientation". The "market orientation" capability is the identification of new market opportunities, recognizing resource gaps and promoting innovation (DESAI et al., 2007). As such, it is important to understand customer needs and the dynamics of the competitive market. According to our interviews, market orientation capability is related to being able to listen to customers' needs, to understand those needs and to improve the company (regarding its products, services and business processes) according to customer knowledge (E1 and E4). In this context, interviewee E1 argues that customers' needs are very dynamic and companies must be aware of it. Moreover, an efficient and challenging way to observe market is to manage social networks (E1).

CRM software may allow companies to be market orientated (E1 and E3). According to interviewees, CRM software is an important tool to access the right customers through the right communication channel, offering, for example, a new product (E1). Many companies, according to interviewee E3, are using CRM systems to enhance the understanding about the market and to help R\&D departments to develop new products and services (E1, E6 and E8).

Finally, our interviewees also talked about "social networking capability". Social networking capability refers to establishing good relationships with supply chain partners in an on-going basis, in order to get useful customer information. This enables the use of complex knowledge and the co-creation of value intentionally from net of stakeholders (DESAI et al., 2007).

One interviewee (E1) acknowledged that the philosophy of CRM is a key factor, as CRM is related to good relationships with all types of stakeholders (suppliers, competitors, governments, etc.), not only with the customers. Another important concept that emerges from the interviews is Social CRM (E1 and E8), in other words, the use of social networks to gather customer and competitors' information. Finally, our interviewees highlighted the importance to use customer knowledge (E2 and E5). Another interviewee (E6) argues that it is important to be able to deal with external knowledge (related to external stakeholders) but is fundamental to be able to manage the internal knowledge.

Therefore, data analysis of the interviews sustains that dynamic capabilities are an important link to explain how CRM practices lead to the creation of innovation capabilities. In fact, resource configuration, social network capability and market orientation are concepts that emerged from the interviews when interviewees related CRM practices with innovation capability.

\section{Research Model}

Based on the content analysis of the interviews regarding each CRM practice dimension and activities, as well as each innovation dimension, we develop a conceptual model for establishing the relationship between CRM practices and innovation capabilities through the dynamic capabilities. The conceptual model proposed here (Figure 2) is based on the information gathered from interviews and was adapted from the previous study of Lin et al. (2010), whilst incorporating the CRM dynamic capabilities proposed by Desai et al. (2007).

The conceptual model reflects the possible influence of CRM practices dimensions and the activities of organizational innovation capabilities, highlighting the mediating role of Dynamic Capabilities in the relationship between CRM practices and Innovation Capabilities. As previously mentioned, all dimensions may have a 
particular role in the organization's strategy. However, only a dynamic combination of all dimensions can provide continuous and sustainable organizational innovation capabilities. The introduction of the Dynamic Capabilities framework in the proposed model is supported by the fact that only with a dynamic search for opportunities and a continuous management of threats will the CRM strategy succeed and support the achievement of innovation. This dynamic procedure must be a mixture of all three elements of the framework (seizing, sensing and managing threats and transformations) and their own micro-foundations. Another particular aspect of this proposed model is that the use of CRM systems may help organizations achieve innovation only if the organization maintains its ability to reorganize itself dynamically; in response to market demands playing a mediating role on leading that the development of CRM practices have a positive effect on innovation capabilities.

Our proposed model is based on the following proposition: CRM practices allow companies to develop dynamic capabilities that enhance innovation capabilities.

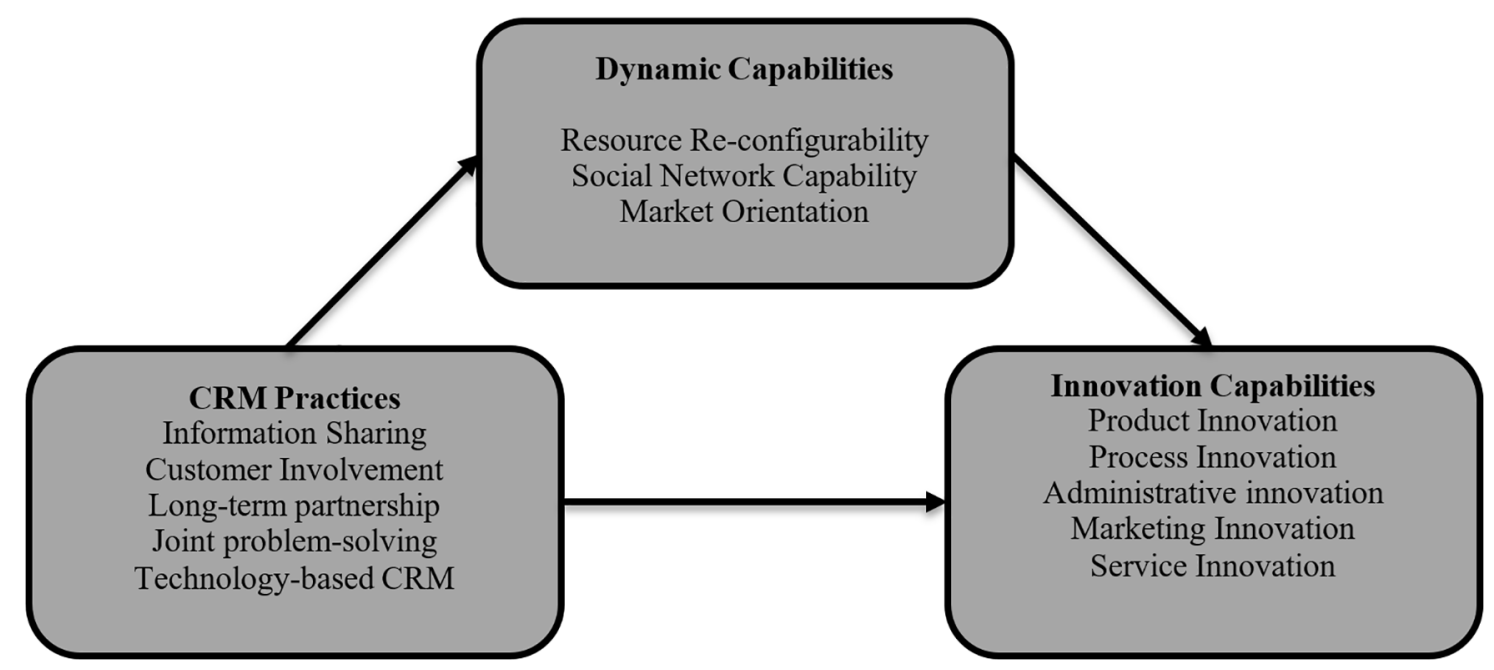

Figure 2. Research model - adapted from Lin et al. (2010), Teece (2007) and Desai et al. (2007)

\section{Final Remarks}

This exploratory research builds an understanding of the influence of CRM systems on organizational innovation capabilities. The methodology applied in this research paper contributes to a deeper understanding of the theoretical background about CRM practices, innovation capability and dynamic capabilities proposing a conceptual model linking these three constructs.

Consultants, academics and managers that participated in this study discussed the capabilities and benefits of CRM systems usage. Depending on the expertise of each interviewee, we were able to understand which CRM practices influence the ability of a company to achieve organizational innovation capability through the implementation of CRM systems. The results of the interviews showed that innovation could be an important point for the business strategy, being a mainstream subject given today's complex and global market that continuously challenge organizations. For this reason, a continuous process of search and development of new product or services considering the framework of dynamic capabilities and based on customer feedback may help organizations to sustain competitive advantage. 
This study contributes to the existing literature regarding CRM as it provides empirical and exploratory evidence on how the usage of CRM may foster the creation of innovation capabilities, which can be explored by organizations already using CRM. Additionally, this paper proposes that the development of innovation capabilities based on the CRM practices through the dynamic capabilities. This important link opens new avenues for future research that may develop a measurement model to test the mediating role of dynamic capabilities of CRM practices and innovation capabilities. For practitioners, our results show that the implementation of CRM system could have innovation creation as a possible expected benefit. This highlights the importance of developing those practices throughout the organization in order to be able to achieve innovation as source of competitive advantages. Many CRM implementations failed in the past as they neglected its complexity. Findings of the present study can also help managers to analyze more carefully the full potential of a CRM system implementation considering the implications it could have on different levels of the organization besides marketing and sales.

This research paper has some limitations. It has a limited number of interviews and they were only conducted in one country. Further research can interview users of CRM systems in order to collect their insights on the impact of CRM in their daily work activities. Regarding the results of this research, particularly to the extent of the literature review, and the proposed model linking CRM practices and innovation capabilities, future research could replicate this study in another country. Furthermore, a case study could be conducted in order to validate the proposition put forward by the present study.

\section{REFERENCES}

ADLER, P. S.; SHENBAR, A. Adapting your technological base: the organizational challenge. Sloan Management Review, v. 32, n. 1, p. 25-37, 1990.

BARDIN L. Análise de conteúdo. 5th Edition. Lisbon: Edições 70, 1977.

BELDI, A., CHEFFI, W.; DEY, P. Managing customer relationship management projects: The case of a large French telecommunications company. International Journal of Project Management, v. 28, n. 4, p. 339-351, 2010.

BRYSON, J. Strategic planning for public and non-profit organizations: A guide to strengthening and sustaining organizational achievement. Vol. 1. John Wiley \& Sons, 2011.

CHEN, I.; POPOVICH, K. Understanding customer relationship management (CRM) People, process and technology. Business Process Management Journal, v.9, n.5, p.672-688, 2003.

COLTMAN, T. Can superior CRM capabilities improve performance in banking. Journal of Financial Services Marketing, v. 12, n. 2, p. 102-114, 2007.

DAY, G. S. The Capabilities of Market-Drive Organizations. Journal of Marketing, v. 58, n. 4, p. 37-52, 1994.

DESAI, D.; SAHU, S.; SINHA, P.K. Role of dynamic capability and information technology in customer relationship management: A study of Indian companies. Vikalpa, v. 32, n. 4, p. 45-62, 2007.

ERNST \& YOUNG CORPORATION. Innovating for the next three billion the rise of the global middle class - and how to capitalize on it. Ernst \& Young Global Limited EYG, No. EX0048, 2011.

FOROUDI, P., JIN, Z., GUPTA, S., MELEWAR, T.C., FOROUDI, M.M. Influence of innovation capability and customer experience on reputation and loyalty. Journal of Business Research, v. 69, n. 11, p. 4882-4889, 2016.

GARRIDO-MORENO, A.; PADILLA-MELÉNDEZ, A. Analyzing the impact of knowledge management on CRM success: The mediating effects of organizational factors. International Journal of Information Management, v. 31, n. 5, p. 437-444, 2011.

GUEST, G.; BUNCE, A.; JOHNSON, L. How many interviews are enough? An experiment with data saturation and variability. Field Methods, v.18, n. 1, p. 59-82, 2006.

GIBBS, G. Qualitative data analysis: Explorations with NVivo (Understanding social research). Buckingham: Open University Press, 2002. 
GLASER, B.; STRAUSS, A. The discovery of grounded theory: Strategies for qualitative research. New York: Aldine Publishing Company, 1967.

JOHNSON, D.S.; CLARK, B.H.; BARCZAK, G. Customer relationship management processes: How faithful are business-to-business firms to customer profitability? Industrial Marketing Management, v. 41, n. 7, p. 1094-1105, 2012.

JENG, D.JF., PARK, A. The variable effects of dynamic capability by firm size: the interaction of innovation and marketing capabilities in competitive industries. International Entrepreneurial Management Journal, v.12, n. 115, 2016.

KERAMATI, A.; MEHRABI, H.; MOJIR, N. A process-oriented perspective on customer relationship management and organizational performance: An empirical investigation. Industrial Marketing Management, v. 39, n. 7, p. 1170-1185, 2010.

KIM, B.Y. Mediated Effects of Customer Orientation on Customer Relationship Management Performance. International Journal of Hospitality \& Tourism Administration, v. 9, n. 2, p. 192-218, 2008.

KHODAKARAMI, F.; CHAN, Y. Exploring the role of customer relationship management (CRM) systems in customer knowledge creation. Information \& Management, v. 51, n. 1, p. 27-42, 2014.

KOZIOŁ, L.; KOZIOŁ, W.; WOJTOWICZ, A.; PYREK, R. Relationship Marketing - A Tool for Supporting the Company's Innovation Process. Procedia - Social and Behavioral Sciences, v. 148, p. 324-329, 2014.

KU, E.C.S. The impact of customer relationship management through implementation of information systems. Total Quality Management \& Business Excellence, v. 21, n. 11, p. 1085-1102, 2010.

LIN, R.; CHEN, R.; CHIU, K. Customer relationship management and innovation capability: an empirical study. Industrial Management \& Data Systems, v. 110, n. 1, p. 111-133, 2010.

MAKLAN, S.; KNOX, S.; RYALS, L. Using real options to help build the business case for CRM investment. Long Range Planning, v. 38, n. 4, p. 393-410, 2005.

MAKLAN, S.; KNOX, S.; RYALS, L. New trends in innovation and customer relationship management: a challenge for market researchers. International Journal of Marketing Research, v. 50, n. 2, p. 221-240, 2008.

NASUTION, H.N.; MAVONDO, F.T.; MATANDA, M.J.; NDUBISI, N.O. Entrepreneurship: Its relationship with market orientation and learning orientation and as antecedents to innovation and customer value. Industrial Marketing Management, v. 40, n. 3, p. 336-345, 2011.

NGAI, E.; LI, X.; CHAU, D. Application of data mining techniques in customer relationship management: A literature review and classification. Expert Systems with Applications, v. 36, n. 2, p. 2592-2602, 2009.

NISULA, A.; KIANTO, A. Evaluating and Developing Innovation Capabilities with a Structured Method. Interdisciplinary Journal of Information, Knowledge and Management, v. 8, p. 59-82, 2013.

PAYNE, A. Handbook of CRM - Achieving Excellence in Customer Management. Burlington, MA, USA: Butterworth-Heinemann, 2005.

PEDRON, C.D.; CALDEIRA, M. Customer relationship management adoption: using a dynamic capabilities approach. International Journal of Internet Marketing and Advertising, v. 6, n. 3, p. 265$281,2011$.

PEDRON, C.D.; PICOTO, W.N.; DHILLON, G.; CALDEIRA, M. Value-focused objectives for CRM system adoption. Industrial Management \& Data Systems, v. 116, n. 3, p. 526-545, 2016.

PLAKOYIANNAKI, E.; TZOKAS, N. Customer relationship management: A capabilities portfolio perspective. Journal of Database Marketing, v. 9, n. 3, p. 228-237, 2002.

RAMAN, P.; WITTMANN, M.C.; RAUSEO, A.N. Leveraging CRM for sales: the role of organizational capabilities in successful CRM implementation. Journal of Personal Selling \& Sales Management, v. 26, n. 1, p. 39-53, 2006.

RAPP, A.; TRAINOR, K.J.; AGNIHOTRI, R. Performance implications of customer-linking capabilities: Examining the complementary role of customer orientation and CRM technology. Journal of Business Research, v. 63, n. 11, p. 1229-1236, 2010.

REINARTZ, W.; KRAFFT, M.; HOYER, W. The customer relationship management process: Its measurement and impact on performance. Journal of Marketing Research, v. 41, n. 3, p. 293-305, 2004.

RITTER, T.; ANDERSEN, H. A relationship strategy perspective on relationship portfolios: Linking customer profitability, commitment, and growth potential to relationship strategy. Industrial Marketing Management, v. 43, n. 6, p. 1005-1011, 2014. 
SAUNDERS, M.N.; THORNHILL, A.; LEWIS, P. Research methods for business students, $5^{\text {a }}$ edição. Harlow, England. Pearson Education Ltd, 2009.

SAUNILA, M. Performance measurement approach for innovation capability in SMEs International Journal of Productivity and Performance Management, v. 65, n. 2, p.162-176, 2016.

SMITH, C., FIXSON, S., PANIAGUA-FERRARI, C.; PARISE, S. The Evolution of an Innovation Capability. Research-Technology Management v. 60, n. 2, p. 26-35, 2017.

SWIFT, S. Accelerating customer relationships: Using CRM and relationship technologies. Prentice Hall Professional, 2001.

TEECE, D.; PISANO, G.; SHUEN, A. Dynamic capabilities and strategic management. Strategic Management Journal, v. 18, n. 7, p. 509-533, 1997.

TEECE, D. Explicating dynamic capabilities: the nature and microfoundations of (sustainable) enterprise performance. Strategic Management Journal, v. 28, n. 13, p. 1319-1350, 2007.

TEECE, D. Business models, business strategy and innovation. Long Range Planning, v. 43, n. 2, p. 172-194, 2010.

TORIANI, S.; ANGELONI, M.T. CRM as a Support for Knowledge Management and Customer Relationship. Journal of Information Systems and Technology Management, v. 8, n. 1, p. 87-108, 2011.

TRAINOR, K. J.; ANDZULIS, J. M.; RAPP, A.; ANIHOTRI, R. Social media technology usage and customer relationship performance: A capabilities-based examination of social CRM. Journal of Business Research, v. 67, n. 6, p. 1201-1208, 2014.

YANG, Y. F. Service capabilities and customer relationship management: an investigation of the banks in Taiwan. The Service Industries Journal, v. 32, n. 6, p. 937-960, 2012.

YIN, R. Qualitative Research from Start to Finish, The Guilford Press, New York, 2011.

WEI-WEI, P.; DONG-SHENG, W. The Development and Application of Customer Relationship Management System. Intelligent Computation Technology and Automation (ICICTA), v. 3. IEEE, 2010.

WEERAWARDENA, J. Exploring the role of market learning capability in competitive strategy. European Journal of Innovation Management, v. 37, n. 3/4, p. 407-429, 2003.

ZABLAH, A.; BELLENGER, D.; JOHNSTON, W. Customer relationship management implementation gaps. Journal of Personal Selling \& Sales Management, v. 24, n. 4, p. 279-295, 2004. 
Appendix 1: Interview Guide

Introduction: (understanding the use and knowledge of the person being interviewed)

- Can you please describe your experience with IT?

- Can you please explain your role in IT projects?

- What is your understanding about CRM?

- On a daily basis, how often do you use CRM systems?

- Which CRM system does your organization work with? Which tools do you use? For how long?

- What were the objectives for CRM adoption in your organization? For what purposes do you use each system? Could you give some examples?

CRM in the organization:

- Are you satisfied with your (company) CRM solution?

- What business processes did the CRM system change? Can you evaluate how many business processes are supported by a CRM system?

- Could you give some explanation of how the CRM system changed business processes? Could you please give some examples?

- How would you describe CRM system capabilities?

- What is your opinion about the degree of utilization of CRM system capabilities?

- Does the CRM system contribute to the improvement of processes and value creation within the company? If yes, please describe how, and give some examples.

Evaluation of CRM systems:

- What benefits do CRM systems provide for you and your organization?

- To what extent do CRM systems successfully and effectively support knowledge creation activities within your department or in the whole organization? Specifically, could you please give examples for each of the following questions?

- Do CRM systems help you gather information and create knowledge that you did not previously have about your customers?

- Do they give you any information about your customers that you previously did not have?

- Do they provide new knowledge that you can share with customers (i.e., knowledge for customers) that you could not previously share with them?

- In your opinion, what are the strengths and weaknesses of your organization's current CRM systems with regard to customer knowledge creation opportunities, analytical capabilities, collaborative capabilities and operational capabilities?

- In general, are you satisfied with your organization's CRM systems capabilities?

- Which organizational factors may have some influence on CRM capabilities?

- How is organizational learning capability important for CRM success and competitive advantage?

- Do you think that business process orientation capability is important for CRM success and competitive advantage?

- How is customer-centric capability important for CRM success and competitive advantage?

- How is task-technology fit capability important for CRM success and competitive advantages?

- How do you measure CRM capability in your organization?

CRM and Innovation Capabilities

- How would you describe innovation capability?

- How is innovation capability measured in your organization?

- Do CRM systems give the organization the ability to come up with ideas consistently? If yes, please describe how and why.

- What are your suggestions for improving CRM systems to match your requirements for knowledge creation?

- How can CRM systems support your organization's R\&D activities? What about service improvements and new product development?

- "Social Capital is a unique resource for an organization" (Adler and Kwon, 2002). Do you support this statement? If yes, how do CRM systems create, develop and elevate the Social Capital of your organization?

- Do you think that CRM capability is important to achieve innovation capability and competitive advantage? If so, how does CRM help your organization achieve innovation capabilities?

Do you think that there is a relationship between CRM system capabilities and innovation capabilities? In which ways?

- Is innovation capability important for your organization in achieving competitive advantages? In which ways? 
Table A1: CRM and Innovation Capabilities

\begin{tabular}{|c|c|c|}
\hline Author & Research question/objectives & Method \\
\hline Keramati et al. (2010) & To specify what resources are important for implementing CRM processes & Case study \\
\hline Rapp et al. (2010) & $\begin{array}{l}\text { To identify how technology and complementary resources are bundled to } \\
\text { form capabilities that foster durable customer relationships }\end{array}$ & Survey \\
\hline Beldi et al. (2010) & $\begin{array}{l}\text { To analyze how to manage CRM implementation projects successfully across } \\
\text { the different phases of the implementation process }\end{array}$ & Case study \\
\hline Johnson et al. (2012) & $\begin{array}{l}\text { To examine the motivational effect of market growth rate and customization } \\
\text { requirements }\end{array}$ & Survey \\
\hline Nasution et al. (2011) & $\begin{array}{l}\text { To evaluate the direct effect of entrepreneurship and business orientation on } \\
\text { innovation and customer value and the interaction effect of entrepreneurship } \\
\text { and business orientation on innovation and customer value. }\end{array}$ & Survey \\
\hline $\begin{array}{l}\text { Garrido-Moreno and } \\
\text { Padilla-Meléndez (2011) }\end{array}$ & $\begin{array}{l}\text { To study knowledge management as the main factor that determines the } \\
\text { successful implementation of CRM }\end{array}$ & Survey \\
\hline Trainor et al. (2014) & $\begin{array}{l}\text { To analyze how social media technology usage and customer-centric } \\
\text { management systems contribute to a firm-level capability of social CRM }\end{array}$ & Survey \\
\hline $\mathrm{Ku}(2010)$ & $\begin{array}{l}\text { To determine how customer-orientated firms use information systems to } \\
\text { affect CRM profitability. }\end{array}$ & Survey \\
\hline $\begin{array}{l}\text { Toriani and Angeloni } \\
(2011)\end{array}$ & $\begin{array}{l}\text { To examine the role of CRM as a support for knowledge management and for } \\
\text { the development of strategies for customer relationship }\end{array}$ & Survey \\
\hline Coltman (2007) & Can superior capabilities improve performance in Banking? & Survey \\
\hline $\begin{array}{l}\text { Ritter and Andresen } \\
(2014)\end{array}$ & $\begin{array}{l}\text { To develop a three dimensional portfolio model for business relationships } \\
\text { which distinguishes between six different categories. }\end{array}$ & Case study \\
\hline Maklan et al. (2008) & $\begin{array}{l}\text { To study how research can provide tools and methods to assist and improve } \\
\text { the co-creation process }\end{array}$ & Case study and action research \\
\hline
\end{tabular}

Table A2: CRM and Dynamic Capabilities

\begin{tabular}{lll}
\hline Author & Research question/objectives & Method \\
\hline Khodakarami and Chan (2014) & To analyze how CRM systems support customer knowledge creation & Case study \\
Raman, Wittmann and Rauseo (2006) & $\begin{array}{l}\text { To explore the factors those contribute to succesfful CRM implementation } \\
\text { in the private sector }\end{array}$ & Interviews \\
Kim (2008) & $\begin{array}{l}\text { To study how customer orientation simulate employee training and } \\
\text { customer information processing capability when firms implement CRM }\end{array}$ & Interviews and survey \\
Yang (2012) & $\begin{array}{l}\text { To verify if CRM performance in the banking industry enhance Case study } \\
\text { differently for each independent capability }\end{array}$ & Case study \\
\hline
\end{tabular}

